\title{
AIDS Awareness Programme on Adult Citizens of Lagos State
}

\author{
Saula Ayinla Shamsideen \\ Adeniran Ogunsanya College of Education Otto-Ijanikin, Lagos, Nigeria
}

\begin{abstract}
The research work focused on AIDS awareness programme on Adult Citizens of Lagos State. Three null hypotheses were formulated for the study and the instrument that was used for the study was questionnaire. A descriptive survey design was adopted for the study. The sample included 100 respondents randomly selected from various areas in Lagos State. Data was analyzed using frequency table, percentage and Chi-square. Based on the results of this study, conclusion was made that counselors are indispensable in the prevention of HIV/AIDS among adult citizens and that effective health education is the antidote for the prevention and spread of the pandemic.
\end{abstract}

\section{Introduction}

One of the leading causes of premature death in the last twenty years has been the scourge of Acquired Immune Deficiency Syndrome (AIDS). The disease, AIDS, was first heard of in 1981. Within twenty years, it spread to all continents of the world and remains a great killer to which no man has found a solution. In 1988 alone, about 5.8 million new cases occurred, bringing the total number of people living with Human Immuno-deficiency Virus/AIDS by December, 1998 to approximately 33.4 million. The Joint United Nations Programme on HIV/AIDS estimates that there are now 40 million people living with HIV or AIDS worldwide [11]. Since the beginning of the epidemic, AIDS has killed more than 25 million people worldwide. It has replaced malaria and tuberculosis as the world's deadliest infectious disease among adults and is the fourth leading cause of death worldwide. Fifteen million children have been orphaned by the epidemic. Young people worldwide are the sub-group most affected while about half of new HIV cases are occurring in people aged 15-24. According to Okonofua it is no longer news that the Human Immuno- deficiency Virus is now well established in Nigeria [9]. Although the virus was first identified in Nigeria in 1988, over 4 million Nigerians were estimated to have contacted the virus by the end of 1998. This makes Nigeria the second country in Africa with the heaviest burden of the disease, in terms of absolute number of those afflicted, second only to South Africa. The disease has now permeated the entire Nigeria society. It affected men and women in urban and rural areas, as well as adolescents, commercial sex workers, traders, high profile politicians and socialites, servicemen and women, truck drivers and students. Indeed, everyone must feel vulnerable to the disease, which is fast rampaging the most productive age groups in the Nigerian population. Several thousands have died from the disease, and this has brought untold hardship and disorganization to many Nigeria families. In Nigeria, the burden of HIV/AIDS on the citizenry is alarming. Statistics on the spread of the disease show that Nigeria records about 1,400 new infections every day. This figure represents one new infection per minute. By October 1998, it is believed that Nigeria records about 571,036 cases of HIV infection. In the hierarchy of the world's most infected AIDS nations, Nigeria is said to occupy the $27^{\text {th }}$ position, constituting 8.9 percent of global infection and 12.5 percent of the African HIV/AIDS burden.

Professor Debo Adeyemi, one time health minister in Nigeria, describes the spread of HIV/AIDS as alarming. According to him, about 25 million adults in Nigeria are already infected with the disease. He reasons that with his figure, assuming that there are no new cases of infection, fatality from the disease will surpass the totality of deaths recorded from the Nigeria civil war by the year 2010 .

The first HIV and AIDS case in Lagos State was recorded in 1986. Since then there has been a gradual but steady increase in the number of people testing positive to HIV and living with AIDS. Although the National zero-prevalence Study puts the prevalence rate of HIV in the state at $4.7 \%$ in 2003 and $3.3 \%$ in 2005 , the facility based studies conducted in the State put the rate at $7 \%$. As at 2001, it was estimated that about 975,000 people were living with the virus in the state. Adolescents and young adults within the youthful age of 15-24 years were the most affected. Like in the other parts of the country, the spread of HIV/AIDS in Lagos State is mainly through unprotected heterosexual activity accounting for about $89.5 \%$ of all infections. Mother-To-Child Transmission (MTCT) and infection through blood 
and other blood products account for about $4.5 \%$ and $3.5 \%$ respectively, while infection through sharp instruments accounts for about $2.5 \%$ of all the transmissions.

Some of the factors responsible for the spread of HIV and AIDS in the state include: poverty, which is very prominent among the low income earners in the state; high level of ignorance about the nature of the disease, the modes of transmission, and preventive strategies; inadequate Sexually Transmitted Diseases (STDs) prevention, diagnosis and treatment, discrimination and stigmatization of People Living with HIV/AIDS (PLWH/A) as well as limited care and support facilities for PLWH/A. Others include unprotected sexual activity among the people, pessimism and fatalistic attitudes, low self risk assessment, break down in traditional value system and lack of adequate sexuality education for our youths, as well as unsafe blood transfusions.

The disease up till now has got no cure despite many years of drug and vaccine research activities. Although few drugs are now available that could prolong the lives of infected persons through reduction of the load of the virus and improvement in the number of white blood cells. Such drugs are, however, very expensive, globally, and quite scarce in Nigeria. Good nutrition and prompt treatment of presenting diseases can also prolong the life of an infected person. Thus, the only effective way of controlling HIV/AIDS, presently, is by prevention, with education as the main thrust of this approach.

\section{Statement of the Problem}

The main thrust of this paper was to determine the rate at which adults come to counsellors for help and understanding. Also, the counsellors' attitudes toward them to determine in large measure the extent to which they will attempt to cope constructively with their problems and undertake positive actions.

\section{Purpose of the Study}

The main purpose of this study is to determine the level of awareness of HIV/AIDS among adult citizens in Lagos State, to assess the precautionary measures taken against the transmission of HIV/AIDS and to appraise the activities of counsellors in the prevention of HIV/AIDS.

\section{Research Questions}

In order to give the research a focus, the following questions were asked: i. Is there any significant relationship between awareness on HIV/AIDS and precautionary practice measures against the transmission of the disease?

ii. In what way has gender influence the precautionary practice measures against the transmission of the disease?

iii. What are the significant roles played by counsellors towards the precautionary measures against the transmission of the disease?

\section{Research Hypotheses}

Ho: $\quad$ There is no significant relationship between awareness of HIV/AIDS and the practice of precautionary measures against the transmission of the disease

Hon : There is no significant difference between male and female adult citizens in their practice of precautionary measures against the transmission of the disease

Ho $_{3}$ : There is no significance relationship between activities of counsellors and precautionary practice measures against the transmission of the disease

\section{Significance of the Study}

The significance of this study is primarily to establish the level of awareness of HIV/AIDS and challenges facing the Adult Citizens in Lagos State, Nigeria. It will also contribute to the public enlightenment about opportunities provided for enhancing, improving and modifying the quantity of education programmes in the state.

\section{Limitations of the Study}

Large numbers of the respondents were found all over the nation owing to time constraint but the study was limited to Ojo Local Government Area of Lagos state.

\section{Research Methodology}

This involved the method and procedures that were followed in carrying out this research, which included the following: 


\section{Research Design}

The study adopted a descriptive survey research design. The survey research design elicit data of large magnitude at the same time reduce time lag. This accounted for the choice of this design.

\section{Population of the Study}

The population of the study consisted of all the Adult citizens in Lagos State.

\section{Sample and Sampling Technique}

The sample for the study consisted of 100 Adult citizens selected in Ojo Local Government Area of Lagos State.

The random sampling technique was adopted. This was adopted in order to cover all parts of the study area and also to give all units of the population an equal chance of being selected. This technique ruled out bias and created room for credibility, reliability and validity of the study.

\section{Instrument for Data Collection}

A self developed questionnaire was used to collect data from the respondents in order to give direct information on the subject under study. This formed the primary source of data. The secondary sources of data included books, journal articles, magazines, newspapers, internet and other publications. All these sources were referenced at the end of the day.

\section{Method of Data Analysis}

The study employed both the descriptive and the inferential statistical methods. In this, the simple percentages and frequency table were used for descriptive inferences to be made.

\section{Results and Discussions}

The data collected through the questionnaire were collated and subjected to statistical test. The percentage distribution method was used to analyse the bio-data and Chi-square Statistical analysis was used to test the hypothesis at 0.05 level of significance. Results and discussion were presented as follows:

Table 1. Gender of Respondents

\begin{tabular}{|c|c|c|}
\hline Variables & Frequency & Percentage \\
\hline Male & 75 & 75 \\
\hline Female & 25 & 25 \\
\hline Total & 100 & 100 \\
\hline
\end{tabular}

The table above shows that majority of the respondents were male with the highest frequency.

Table 2. Qualification of Respondents

\begin{tabular}{|c|c|c|}
\hline Variables & Frequency & Percentage \\
\hline Senior Secondary School Cert. & 34 & 34 \\
\hline First Degree & 47 & 47 \\
\hline Others & 19 & 19 \\
\hline Total & $\mathbf{1 0 0}$ & $\mathbf{1 0 0}$ \\
\hline
\end{tabular}

From the table above, majority of the respondents were First degree holders.

Table 3. Religion of Respondents

\begin{tabular}{|c|c|c|}
\hline Variables & Frequency & Percentage \\
\hline Islam & 53 & 53 \\
\hline Christianity & 47 & 47 \\
\hline Total & $\mathbf{1 0 0}$ & $\mathbf{1 0 0}$ \\
\hline
\end{tabular}

The table above shows that majority of the respondents were Muslims with the highest frequency.

Table 4. Age Distribution of Respondents

\begin{tabular}{|c|c|c|}
\hline Variables & Frequency & Percentage \\
\hline $20-29$ & 18 & 18 \\
\hline $30-39$ & 25 & 25 \\
\hline
\end{tabular}




\begin{tabular}{|c|c|c|}
\hline $40-49$ & 15 & 15 \\
\hline $50+$ & 42 & 42 \\
\hline Total & $\mathbf{1 0 0}$ & $\mathbf{1 0 0}$ \\
\hline
\end{tabular}

The table above reveals that majority of the respondents were within the age of 50 years and above.

\section{Testing of Hypotheses}

\subsection{Hypothesis 1}

There is no significant relationship between awareness of HIV/AIDS and the practice of precautionary measures against the transmission of the disease

Table 5. Result Showing the Relationship Between Awareness of HIV/AIDS and the Practice of Precautionary Measures

\begin{tabular}{|l|l|l|l|l|l|l|l|l|l|}
\hline Groups & A & D & U & Total & df & P & $\begin{array}{l}\text { Cal } \\
X^{2}\end{array}$ & $\begin{array}{l}\text { Table } \\
X^{2}\end{array}$ & Decision \\
\hline Male & 40 & 10 & 25 & 75 & 2 & 0.05 & 7.24 & 5.99 & Reject \\
\cline { 1 - 4 } & 15 & 7 & 3 & 25 & & & & & \\
\cline { 1 - 5 } Total & 55 & 17 & 28 & 100 & & & & & \\
\hline
\end{tabular}

The table above shows that calculated value is greater than the table value, thus the null hypothesis which states that there is no significant relationship between awareness of HIV/AIDS and the practice of precautionary measures is rejected. This implies that there is a significant relationship between awareness of HIV/AIDS and the practice of precautionary measures against the transmission of the disease.

Discussion:

The findings of the first hypothesis point out that there is a significant relationship between awareness of HIV/AIDS and the practice of precautionary measures against the transmission of the disease. This finding is supported by the findings of Odebiyi and Olowu in their survey study of attitudinal and behavioural factors in the transmission of the HIV virus [6]. They asserted that the major roles that psychologist/counselors could play in addressing the AIDS epidemic is maintaining vigorous research programme that could construe the cognitive, affective and behavioural aspects of the individual on the HIV/AIDS problems. The result showed that adults being aware of the deadly disease (AIDS) take necessary precautionary measures against its transmission.

\subsection{Hypothesis 2}

There is no significant difference between male and female adult citizens in their practice of precautionary measures against the transmission of the disease

Table 6. Result Showing the Relationship Between Male and Female Adults Practices of Precautionary Measures Against the Transmission Disease

\begin{tabular}{|c|c|c|c|c|c|c|c|c|c|}
\hline Groups & $\mathrm{A}$ & $\mathrm{D}$ & $\mathrm{U}$ & Total & $\mathrm{df}$ & $\mathrm{P}$ & $\begin{array}{l}\text { Cal } \\
X^{2}\end{array}$ & $\begin{array}{c}\text { Table } \\
\mathrm{X}^{2}\end{array}$ & Decision \\
\hline Male & 38 & 13 & 24 & 75 & \multirow[t]{3}{*}{2} & \multirow[t]{3}{*}{0.05} & \multirow[t]{3}{*}{5.71} & \multirow[t]{3}{*}{5.99} & \multirow[t]{3}{*}{ Accept } \\
\hline Female & 8 & 10 & 7 & 25 & & & & & \\
\hline Total & 46 & 23 & 31 & 100 & & & & & \\
\hline
\end{tabular}

The table above shows that the calculated value is less than the table value, thus null hypothesis which states that there is no significant difference between male and female students' practice of the precautionary measures against the transmission of the disease is accepted. This implies that there is no significant difference between male and female adult citizens in their practice of precautionary measures against the transmission of HIV/AIDS. This shows that both male and female adult citizens have the same attitude/ behavior towards the practice of precautionary of measures against the transmission of HIV/AIDS.

Discussion:

The findings of the second hypothesis point out that there is no significant difference between male and female adult citizens' practice of precautionary measures against the transmission of HIV/AIDS. This finding agrees with that of Reich and Painter who revealed that some minority gay men believe that oral 
intercourse is safe [10]. This perception may be significant determinants of their involvement in the practice of unsafe sex that pose either high risks for HIV infection. The results show that both male and female secondary school students have the same attitude/behaviour towards the practice of precautionary measures against the transmission of HIV/AIDS

\subsection{Hypothesis 3}

There is no significance relationship between activities of counsellors and precautionary practice measures against the transmission of the disease

Table 6. Result Showing the Relationship Activities of Counselors and Precautionary Practice Measures Against the Transmission Disease

\begin{tabular}{|c|c|c|c|c|c|c|c|c|c|}
\hline Groups & A & D & U & Total & df & P & $\begin{array}{c}\text { Cal } \\
X^{2}\end{array}$ & $\begin{array}{c}\text { Table } \\
\mathrm{X}^{2}\end{array}$ & Decision \\
\cline { 1 - 5 } Male & 38 & 13 & 24 & 75 & 2 & 0.05 & 15.03 & 5.99 & Accept \\
\cline { 1 - 5 } Female & 3 & 10 & 12 & 25 & & & & & \\
\hline Total & 41 & 23 & 36 & 100 & & & & & \\
\hline
\end{tabular}

The table above shows that calculated value is greater than the table value, the null hypothesis which states that there is no significant relationship between activities of counsellors and the practice of precautionary measures against the transmission of HIV/AIDS is rejected. This implies that activity of counsellors have significant relationship with the practice of precautionary measures against the transmission of HIV/AIDS.

Discussion:

The third hypothesis which stated that Counselor's activities have no significant relationship with the practice of precautionary measures against the transmission of HIV/AIDS was rejected. This shows that Counsellor's activities have relationship with adult citizens' practice of precautionary measures against the transmission of HIV/AIDS. The reason for this might be due to the fact that counselor's effectiveness in the performance of their duties as it relates to the provision of information on sex education and health related issues have assisted students in the various steps that they took against the transmission of AIDS.

\section{Conclusion}

From the analysis of the data and the interpretation of results, it can be concluded from this study that the level of awareness of HIV/AIDS among the adult citizens was high. Majority of the respondents indicated that they had heard about AIDS. Also, most believed that there is AIDS. However, some indicated that they have never seen an AIDS patient. With regard to how AIDS can be contacted, majority of the respondents indicated through sharing of syringes, blade and shaving kits, sexual intercourse with an infected person, transfusion of infected blood and homosexuality.
Awareness of HIV/AIDS had a significant relationship with the practice of precautionary measures against the transmission of the disease. There was also a significant relationship between activities of counselors and the practice of precautionary measures. The results however showed no significant difference between male and female adult citizens in their practice of precautionary measures against the transmission of HIV/AIDS.

The role of the counsellor in preventing HIV/AIDS cannot be underestimated. They play important role in contributing to the adults' own self understanding and growth. Pending the discovery of an effective vaccine or therapy, effective health education is the only antidote for the prevention and spread of the pandemic among adult citizens.

\section{Recommendations}

To overcome the limitation of implementation and bring it at par with policy statement the following are recommended:

i. There is need for more HIV/AIDS awareness programmes to be carried out on a continuous basis for people both in rural and urban settings;

ii. HIV/AIDS awareness education should be incorporated into school curriculum from primary to tertiary level;

iii. Wide spread publicity about the presence and prevention of HIV/AIDS among the population in the community through social media networks, religious leaders and traditional heads should be encouraged;

iv. Stigmatization of patients with HIV/AIDS should be discouraged. 


\section{References}

[1] Adegoke, A.A (2004). Influences of HIV/AIDS Public Enlightenment Campaigns on sexual behaviour of inschool adolescents in Ibadan Metropolis. Unpublished Ph.D Thesis, O.A.U, Ife.

[2] Burton, D. (2000). Research Training for Social Scientists. London : SAGE Publications.

[3] Flemings, D.O. \& Mmembe, C. K. (1988). Attitudes, Behaviour and Infection control among Zambiam Dental Personnel Concerning HIV/AIDS Infection. African Dental Journal. 2, p 48 - 53

[4] Haour-Knipe (1999). HIV/AIDS Prevention for migrants and ethnic minorities: three phases of evaluation and medicine, 49, 1357-1372

[5] Isiugo-Abanihie, U.C (1993). Sexual Behaviour and Exposure to the Risk of AIDS in Nigeria.Faculty Lecture for Department of Sociology. University of Ibadan, Nigeria

[6] Odebiyi, A.I, and Olowu, A.A (1991). AIDS in Africa; Psychosocial and Economic Analysis. Scandinavian Journal of Development Alternatives.Vol.10, No. 1\&2, p $45-47$

[7] Odeyomi, O. (1999). HIV/AIDS Epidemic: A Call for Action. Women's Health Forum. Vol.4, No2, p 39-5

[8] Ogundipe, S. 2005). "Hospitals to pay N.5 fine for transfusing HIV - infected blood". The Vanguard, 22 April, www.Vanguardngr.com

[9] Okonofua, F(1999). HIV/AIDS Epidemic: Call for a Pragmatic National Response. Women's Health Forum,vol.4, No2 p 25-38

[10] Reich, J.W, and Painter, J.H (1994). Attitudinal Maintenance of Cognitive Categorization. Dissertation Abstract International. 2, 1-A, p 60-66

[11] UNAIDS/WHO (2007). Report on the Global AIDS Epidemic. Geneva. World Bank (2005). The HIV/AIDS Epidemic in Nigeria. HIV/AIDS Policy Factsheet.

[12] World Bank Portfolio for Nigeria. Available at http://www.kff.org/hivaids/upload/7363.pdf 